\title{
Mineral replacement reactions in naturally occurring hydrated uranyl phosphates from the Tarabau deposit: Examples in the $\mathrm{Cu}-\mathrm{Ba}$ uranyl phosphate system
}

\author{
André Jorge Pinto ${ }^{\mathrm{a}, *}$, Mário A. Gonçalves ${ }^{a}$, Cátia Prazeres ${ }^{b}$, José Manuel Astilleros ${ }^{c, d}$, Maria João Batista ${ }^{\text {b }}$ \\ a Department of Geology and CREMINER/IARSys, Faculty of Sciences, University of Lisbon, Ed. C6, 1759-016 Lisbon, Portugal \\ b LNE G, National Laboratory for Energy and Geology, Bairro do Zambujal, Ap. 7586, 2611-901 Amadora, Portugal \\ ' Department of Crystallography and Mineralozy, Faculty of Geological Sciences, University Complutense of Madrid, C/ José Antonio Novais 2, Madrid 28040, Spain \\ anstitute of Geosciences (UCM-CSIC), C/ José Antonio Novais 2, Madrid 28040, Spain
}

Keywords:

Uranyl phosphate

Mineral replacement

Dissolution-precipitation reaction

Nisa deposit

\begin{abstract}
A B S T R A C T
Uranyl phosphates are a mineral group which include a wide range of different species, each containing specific cations within the hydrated interlayer, and often display a geochemical/mineralogical relationship with $\mathrm{Fe}$ (III) oxy-hydroxides. The environmental relevance of these U-phases arises from their low solubility at most surface and groundwater conditions, where they can ultimately control aqueous $U$ levels. In the present work, samples of naturally occurring uranyl phosphates from the Tarabau site, included in the Nisa deposit, located in central-eastern Portugal, are studied with X-ray diffraction (XRD), Electron Microprobe (EMP) and Scanning Electron Microscopy, with the purpose of $i$ ) identifying uranyl phosphate mineral paragenesis, ii) assessing chemical homogeneity and stoichiometry of the most relevant phases and iii) unraveling possible textural features of mineral reequilibration processes. $\mathrm{XRD}$ studies revealed that the analyzed samples comprehend metatorbernite-like structures, consistent with $\mathrm{Cu}\left(\mathrm{UO}_{2}\right)_{2}\left(\mathrm{PO}_{4}\right)_{2} \cdot 8 \mathrm{H}_{2} \mathrm{O}$ formula. Further EMP determinations allowed the definition of nearly stoichiometric $\mathrm{Cu}$ and $\mathrm{Ba}$ hydrated uranyl phosphates; $\mathrm{Cu}_{x} \mathrm{Ba}_{1}{ }_{x}\left(\mathrm{UO}_{2}\right)_{2}\left(\mathrm{PO}_{4}\right)_{2} \cdot n \mathrm{H}_{2} \mathrm{O}$ intermediate compositions and interlayer cation-depleted phases. The obtained results, combined with textural observations, al lowed us to decipher mineral reequilibration reactions affecting the studied samples. Thus, reactive paths involving the replacement of $\mathrm{Cu}$-bearing by Ba-bearing uranyl phosphates, cation-bearing uranyl phosphate by cation-depleted uranyl phosphate and cation-bearing uranyl phosphate by Fe, $\mathrm{Al}$ oxy-hydroxides have been defined. However, the studied textural features point toward two different mechanisms of mineral replacement, with superimposed expressions. On one hand, the replacement of $\mathrm{Cu}$ by $\mathrm{Ba}$ uranyl phosphate phases, and these last by oxy-hydroxides, takes place by coupled dissolution-precipitation reactions. On the other hand, cation depletion affecting uranyl phosphates occurs by a cation exchange process, possibly giving rise to increasing mineral porosity.
\end{abstract}

\section{Introduction}

The mobility of uranium in the environment has recently received increasing concern, mostly due to issues regarding storage and disposal of spent nuclear fuel, following a resurgence of interest in nuclear energy (Ewing, 2006a). A good example of the need for safe geological repositories with large storage capacities was embodied by projects such as the Yucca Mountain (National Research Council, 1995), intended to become the major national storage system for high level nuclear waste in the USA, until recent termination of development funding by the government administration. However, other counries took final decisions toward repository consuction, such as Sweden and Finland. Most notably, the assessment of safety standards and

* Corresponding author.

E-mail addresses: afipinto@fc.ul.pt (A.J. Pinto),mgoncalves@fc.ul.pt

(M.A. Gonçalves), jmastill@geo.ucm.es (J.M. Astilleros), mjoao.batista@lneg.pt

(M.J. Batista). suitability of such sites requires a deep understanding of uranium geochemistry and mineralogy under a wide range of surface conditions, a strategy highly stressed in recent publications devoted to the environmental aspects of the nuclear fuel cycle (e.g. Ewing, 2006b).

Another important aspect involving long-term behavior of uranium in the environment concerns the development of remediation strategies for contaminated sites. Apart from technically complex and highly expensive bioremediation methods (e.g. Bargar et al., 2008), in situ stabilization using reactive barriers which inorganically trigger the formation of insoluble uranium-bearing phases in oxidative conditions, is an option under scientific scrutiny (e.g. Naftz et al., 1999; Bostic et al., 2000; Fuller et al., 2002). Among the several possible inorganic mechanisms of uranium removal from a contaminated aqueous fluid, the precipitation of low-solubility uranyl phosphates (e.g. Airey, 1986; Fuller et al., 2002; Jerden and Sinha, 2003) presents several technicaleconomical advantages. For instance, stability fields well within most natural surface and groundwater conditions (mildly acidic, atmospherically buffered $\mathrm{pO}_{2}$ and $\mathrm{pCO}_{2}$, low temperature, etc.), extremely low 
mineral reactivity, and cheaper, simpler system maintenance. In fact, uranyl phosphates may control U concentrations in many natural waters, since they involve lower solubilities than, for instance, uranyl silicates, and are common minerals in most weathered $U$ deposits (Finch and Murakami, 1999). Nevertheless, phosphate availability may not exclusively control U mobility, but also limit REE dispersion around primary ores. For instance, Stille et al. (2003) have studied REE aqueous mobility in the vicinities of the natural fission reactor at Bagombé, Gabon, and among their findings is the establishment of uranyl phosphates as an important lanthanide and actinide sink. The most studied occurrences of uranyl phosphates are by far the Koongarra $U$ deposit in Northem Australia, where a wide variety of $U$ minerals has been identified, from the alteration of uraninite to the subsequent uranyl phosphate paragenesis (Snelling, 1980, 1992; Isobe et al., 1992, 1994; ). Other corner stone studies performed in Koongarra samples focused in unraveling the equilibrium relationships between $\mathrm{Fe}(\mathrm{III})$ oxy-hydroxides and uranyl phosphates (e.g. Payne et al., 1992; Murakami et al., 1997; Sato et al, 1997; Payne et al., 2001; Murakami et al., 2005), being the produced reaction path models applied to interpret other similar deposits (e.g. Jerden and Sinha, 2003; Jerden et al., 2003).

The mineralogy of uranyl-phosphates can be subdivided into two major groups: the autunite-group minerals, crystallizing in the tetragonal or pseudotetragonal crystal systems, with U:P ratios of $1: 1$; and the phosphuranylite-group, including orthorhombic species with U:P ratio of $3: 2$. The crystal structure of these minerals may be briefly described as parallel sheets of $\left[\mathrm{UO}_{2} \mathrm{PO}_{4}\right]_{n}^{\mathrm{n}-}$ with a hydrated interlayer containing water-coordinated cations, coexisting with $\mathrm{UO}_{2}^{2+}$ in the case of phosphuranylite-group minerals. An extensive review of the crystal chemistry of many uranyl minerals is included in Burns (1999), approaching the specific ion topology of representative uranyl phosphates.

In the present work we focus on the mineralogical and chemical study of samples of naturally occurring uranyl phosphates from the Tarabau deposit in the Alto Alentejo uranium province, located in the region of Nisa, central-eastem Portugal, with the aim of i) identifying the uranyl phosphate mineral paragenesis, ii) assessing chemical homogeneity and stoichiometry of the most relevant phases and iii) unraveling possible textural features of mineral reequilibration processes.

\section{Geological setting}

The Alto Alentejo uranium province is located in the region of the town of Nisa and is constituted by several small deposits and occurrences scattered along the northern border of the arc shaped Nisa granite and its contact aureole (Fig. 1). Unlike other major uranium deposits in Portugal, none of the deposits in the Nisa region has been exploited but they have been extensively studied as a result of several exploration works including radiometric surveys, drill cores, exploration pits and trenches, and experimental mining operations. Estimated reserves amount to $3.45 \times 10^{6}$ metric tons of ore, with an average grade of $0.12 \%$ of $\mathrm{U}_{3} \mathrm{O}_{8}$ (Prazeres, 2011). The Nisa granite contacts the Schist and Greywacke complex (Beiras Group) of upper preCambrian-lower Cambrian age along its northem border (Solá, 2007; González Menéndez et al., 2011). The host metasediments to the North are low grade metamorphic schists with biotite + muscovite + chlorite + quartz + albite, but a contact aureole 1 to $1.5 \mathrm{~km}$ wide is outlined by spotted schist with cordierite porphyroblasts mostly retrograded to quartz + biotite (González Menéndez et al., 2011; Prazeres, 2011). A network of predominantly NNW-SSE late Variscan faults cut the granite massif and the host lithologies. The mineralization observed occurs at the surface and is constituted by uranyl phosphate minerals of the autunite group and/or meta-autunite group, mostly torbernite $\left(\mathrm{Cu}\left(\mathrm{UO}_{2}\right)_{2}\left(\mathrm{PO}_{4}\right)_{2} \cdot 8-12 \mathrm{H}_{2} \mathrm{O}\right)$, uranocircite $\left(\mathrm{Ba}\left(\mathrm{UO}_{2}\right)_{2}\left(\mathrm{PO}_{4}\right)_{2} \cdot 6-12 \mathrm{H}_{2} \mathrm{O}\right)$ and saléeite $\left(\mathrm{Mg}\left(\mathrm{UO}_{2}\right)_{2}\left(\mathrm{PO}_{4}\right)_{2} \cdot 8-1 \mathrm{H}_{2} \mathrm{O}\right)$. This mineralization results from a late episode of supergene uranium mobilization during Quaternary times and occurs along the late fractures and faults, part of them previously reactivated during the alpine orogenic cycle and important conduits for supergene fluid circulation. In the schists the mineralization is disseminated along discrete fractures, cleavage plans, and cavities within the altered retrograded porphyroblasts. Primary uranium ore minerals identified as uraninite and pitchblende were documented at depth and observed in some drill cores in exploration reports (Prazeres, 2011).

\section{Experimental}

Samples of uraniferous materials were collected from the Tarabau deposit, located in the municipality of Nisa, central Portugal (Fig. 1).

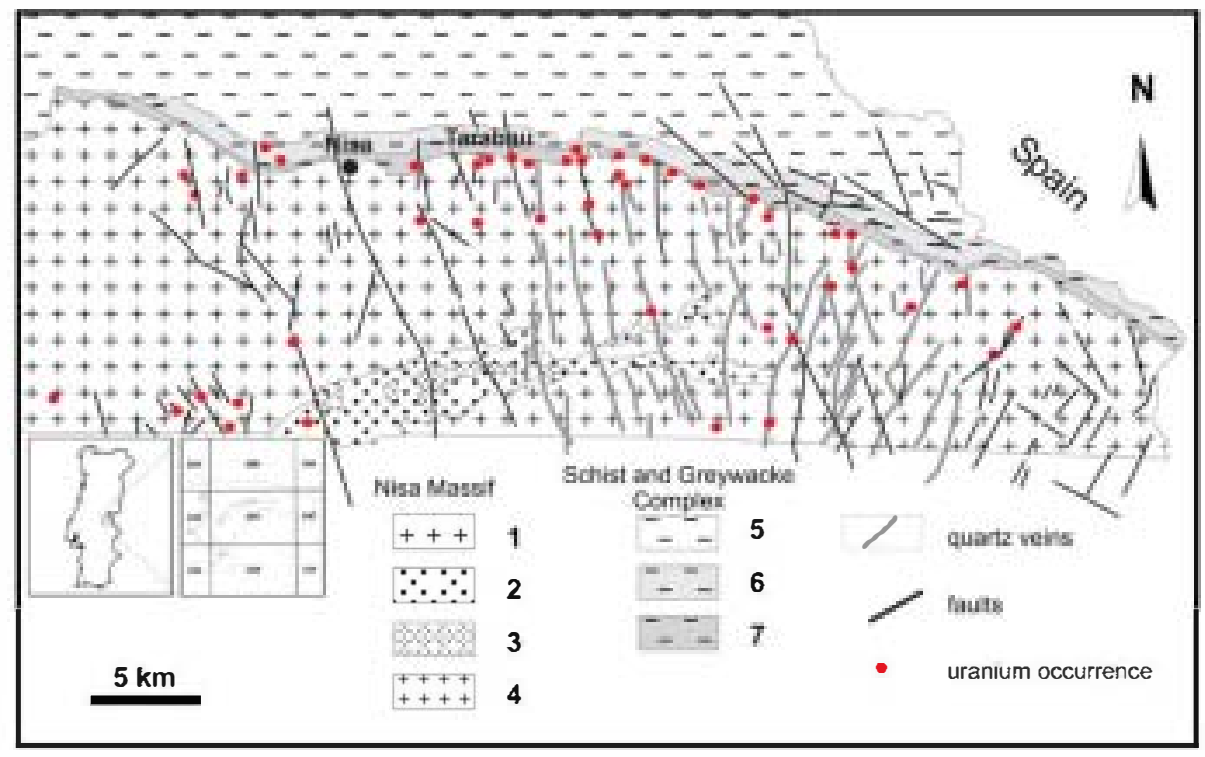

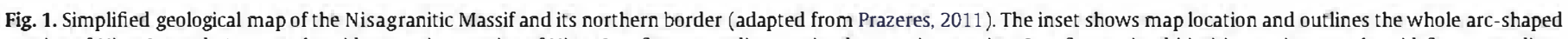

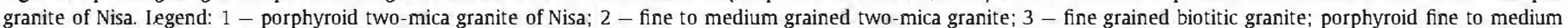

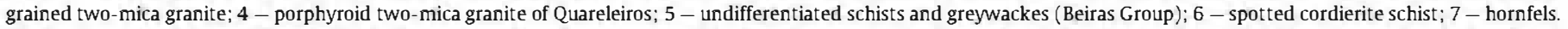

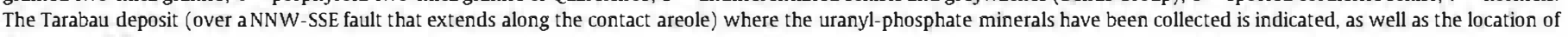
the town of Nisa. 
These minerals occur mostly along fractures and fault borders (striking NNW-SSE), disseminated within fault breccias of deeply weathered granite blocks. They also occur along the grain boundaries of the quartz veins associated with the same fracturing system. Their mode of occurrence and textural relationships clearly indicate that they are late mineral phases, probably associated with the development of the weathering profile during the Quaternary. Sampling included quartz veins and fault breccias from which the uranyl phosphate minerals were later separated. After preliminary inspection of the occurrence modes (overgrowths, inclusions, aggregates, etc.) the uranyl phosphate minerals were individually selected, grain by grain, using a stereomicroscope and separated based on optical criteria. A fraction of the resulting uranyl phosphate concentrates were washed with ethanol in an ulrasound bath, dried at room temperature and powdered for X-ray diffraction (XRD) analysis. Diffraction pattems were obtained using a Philips PW-1830 diffractometer and scanning from $5^{\circ}$ to $80^{\circ}$ (20) with a step size of $0.02^{\circ}$, using CuK $\alpha$ radiation and a graphite crystal monochromator. The diffractometer was calibrated with an external silicon ( $\mathrm{Si}$ ) standard.

Fresh samples of the Tarabau outcrop were also embedded in resin, polished and optically checked with a petrographic microscope, under reflected light. Polished thin sections were also prepared to view under the transmitted and reflected light microscope. After marking target zones on both types of polished sections, the samples were coated with carbon for chemical determinations with an Electron Microprobe (EMP). The employed EMP was a Jeol JXA-8200, equipped with four WDS spectrometers, an EDS spectrometer, and a backscattered electron detector (BSE) which allowed selecting the best surfaces to analyze. Standard analyses applied $5 \mu \mathrm{m}$ of beam diameter, $15 \mathrm{kV}$ and $2.5 \times 10^{-8} \mathrm{~A}$ of beam voltage and intensity, respectively. For metatorbernite and some poorly polished zones or soft phases, analytical conditions were changed to $20 \mu \mathrm{m}$ of beam diameter and $2.5 \times 10^{-9} \mathrm{~A}$ of intensity. The analytical errors derived from count statistics of measurements performed in selected standard materials were $0.3 \%$ for $\mathrm{CaO}$ (apatite standard), $0.4 \%$ for $\mathrm{P}_{2} \mathrm{O}_{5}$ (apatite standard), $0.5 \%$ for $\mathrm{CuO}$ (cuprite standard), $1.8 \%$ for $\mathrm{UO}_{3}$ (uraninite standard), $<1 \%$ for $\mathrm{MnO}$ (bustamite standard), $0.2 \%$ for $\mathrm{Na}_{2} \mathrm{O}$ (albite standard), $0.3 \%$ for $\mathrm{TiO}_{2}$ (rutile standard), $1 \%$ for $\mathrm{BaO}$ (benitoite standard), $1.2 \%$ for $\mathrm{ZnO}$ (willemite standard), $0.8 \%$ for $\mathrm{Al}_{2} \mathrm{O}_{3}$ (plagioclase standard), $0.3 \%$ for $\mathrm{SiO}_{2}$ (almandine standard), $0.4 \%$ for $\mathrm{Fe}_{2} \mathrm{O}_{3}$ (hematite standard), $<1 \%$ for $\mathrm{SO}_{3}$ (celestite standard), $0.5 \%$ for $\mathrm{MgO}$ (periclase standard), $0.1 \%$ for $\mathrm{Cr}_{2} \mathrm{O}_{3}$ (chromium oxide standard) and $0.4 \%$ for $\mathrm{V}_{2} \mathrm{O}_{3}$ (V-metal standard).

When found relevant for the study, unprocessed mineralogical specimens where mounted in an aluminium sample holder, coated with carbon and imaged in the microprobe in scanning mode.

\section{Results}

\subsection{X-ray diffraction: mineral identity}

Fig. 2a displays the powder XRD diffractogram obtained for a sample of the selected uranyl phosphate materials. A comparison can be established with a reference diffraction pattern of metatorbernite, $\mathrm{Cu}\left(\mathrm{UO}_{2}\right)_{2}\left(\mathrm{PO}_{4}\right)_{2} \cdot 8 \mathrm{H}_{2} \mathrm{O}$, shown in Fig. $2 \mathrm{~b}$ extracted from the PDF-2 database (P350316, Vochten et al., 1981).

The obtained powder $\mathrm{XRD}$ results display a good level of agreement with the reference information concerning metatorbernite, despite the occurrence of some minor peaks not attributed to this last phase (i.e. at $\mathrm{d} \dot{A} \approx 3.72,3.35,2.99$, etc.). During sample preparation it was impossible to remove completely all the superficial clay and iron oxide present in microscopic proportions, however the diffractogram is clearly dominated by a set of reflections $002,101,102,110004,104,200,202$, etc. (at $\mathrm{d} \dot{A} \approx 8.70,6.49,5.45,4.96,4.34,3.68,3.49,3.23$ etc., respectively) consistent with a metatorbemite-like phase. Most peaks could also involve reflections of a metauranocircite I phase, $\mathrm{Ba}\left(\mathrm{UO}_{2}\right)_{2}\left(\mathrm{PO}_{4}\right)_{2} \cdot 8 \mathrm{H}_{2} \mathrm{O}$, since

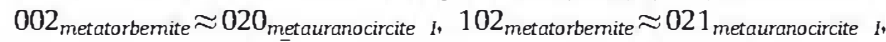
$110_{\text {metatorbemite }} \approx 101 / \overline{1} 01_{\text {metauranocircite l, }}$ etc. Nevertheless, reflections exclusively assignable to a metauranocircite I-type phase do not occur, but the inverse is true for metatorbemite. A closer inspection of both patterns reveals a systematic peak shifting in the measured sample toward lower $2 \theta$ angles with respect to the reference diffractogram $\left(\Delta 2 \theta \approx-0.07^{\circ}\right)$. On one hand, the systematic peak shifting should correspond to deviations from an ideal, pure metatorbemite composition. One the other hand, an assessment of the sample chemical homogeneity based on peak broadening (Fernández-González et al., 2007) is not possible without reference FWHMhkl values concerning measurements performed to naturally occurring pure-endmembers of the metatorbernite-metauranocircite joint. Such issue will be tackled by quantitative EMP microanalyses, presented in Section 4.3. Finally, the occurrence of reflections assignable to other hydrates with $n \mathrm{H}_{2} \mathrm{O} \neq 8$ has not been observed.

\subsection{Crystal morphology of selected uranyl phosphates}

Autunite-group minerals are usually described in the literature using tetragonal settings, being most commonly assigned point group $4 / \mathrm{m}$; occasionally $4 / \mathrm{m} 2 / \mathrm{m} 2 / \mathrm{m}$ pseudosymmetry is also acknowledged, as in the case of metatorbernite, metazeunerite, $\mathrm{Cu}\left(\mathrm{UO}_{2}\right)_{2}\left(\mathrm{AsO}_{4}\right)_{2} \cdot 8 \mathrm{H}_{2} \mathrm{O}$, or chernikovite, $\left(\mathrm{H}_{3} \mathrm{O}\right)_{2}\left(\mathrm{UO}_{2}\right)_{2}\left(\mathrm{PO}_{4}\right)_{2} \cdot 6\left(\mathrm{H}_{2} \mathrm{O}\right)$, external shapes (Ross et al., 1964; Locock and Bums, 2003). However, exceptions occur, such as saléeite, $\mathrm{Mg}\left(\mathrm{UO}_{2}\right)_{2}\left(\mathrm{PO}_{4}\right)_{2} \cdot 10 \mathrm{H}_{2} \mathrm{O}$ (monoclinic; Miller and Taylor, 1986), metauranocircite I (monoclinic; Locock et al, 2005), and

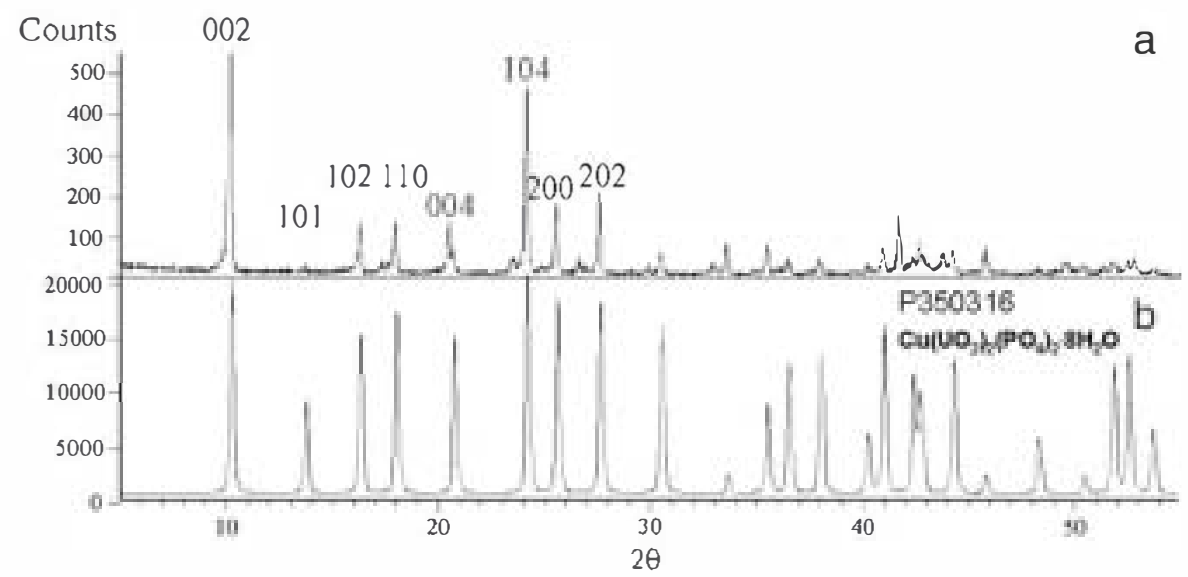

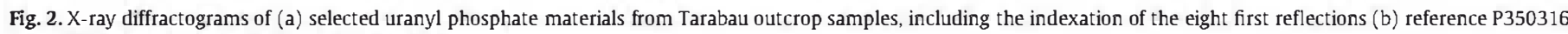
from PDF-2 file, relative to $\mathrm{Cu}\left(\mathrm{UO}_{2}\right)_{2}\left(\mathrm{PO}_{4}\right)_{2} \cdot 8 \mathrm{H}_{2} \mathrm{O}$. 
II, $\mathrm{Ba}\left(\mathrm{UO}_{2}\right)_{2}\left(\mathrm{PO}_{4}\right)_{2} \cdot 6 \mathrm{H}_{2} \mathrm{O}$ (monoclinic; Khosrawan-Sazedj, 1982; Locock et al., 2005), or phosphuranylite, $\mathrm{KCa}\left(\mathrm{H}_{3} \mathrm{O}\right)_{3}\left(\mathrm{UO}_{2}\right)_{7}\left(\mathrm{PO}_{4}\right)_{4} \mathrm{O}_{4} \cdot 8 \mathrm{H}_{2} \mathrm{O}$, (orthorhombic; Hogarth and Nuffield, 1954; Demartin et al., 1991; Piret and Piret-Meunier, 1991). Crystal determinations performed for the two different hydrates of metauranocircite, nonetheless, reveal that both $a$ and $c$ axes share similar dimensions, as well as $\boldsymbol{\beta}$ angles very close to $90^{\circ}$. As a result, such symmetry can be considered to be pseudotetragonal, more suitable for establishing morphological comparisons. Since the previously presented XRD results did not include any reflections assignable exclusively to a saléeite-like phase - only metatorbemite reflections occur - all of the following morphological considerations arise from the application of teragonal $4 / m$ symmetry.

Fig. 3a displays a SEM backscattered electrons (SEM-BSE) micrograph of a grain, corresponding to a lamellar aggregate of uranyl phosphate individuals of tabular shape, obtained during specimen selection. The surface roughly parallel to the image plane corresponds to a cleavage surface, related to the $\{001\}$ pinacoid, and the side faces are poorly developed, as shown along the individual stacking direction in the upper left corner of Fig. 3a. A detailed inspection of the cleavage surface, depicted in Fig. 3b, reveals a pattern of linear features, consisting of more or less prominent edges at $90^{\circ}$ angles from each other. Such linear elements can be interpreted as the expression of side faces intersecting the cleavage surface. In fact, the intersection between $\{001\}$ and $\{0 \mathrm{kI}$, or $\{0 k 0\}$, forms originates edges parallel to [100] and [010]. Other linear features of minor importance occur, parallel to [110] and [110], bisecting the angle formed between [100] and [010]. These minor edges may correspond to the intersection between ( $h h l)$ or $(h h 0)$ side faces and the cleavage surface. Overall, the observed morphology of sampled uranyl phosphates can be described as a \{001\} dominant pinacoid, modified by $\{0 \mathrm{kl}\}$, and occasionally $\{h h l\}$, bipyramids; or $\{h 00\}$ and $\{h h 0\}$ tetragonal prisms. A simulation of hypothetical forms can be checked in Fig. 2c, corresponding to the $4 / m$ point group symmetry. The chosen forms for the simulation correspond to $\{001\},\{011\}$ and $\{113\}$, by order of decreasing importance.

The selected uranyl phosphate grains are seldom covered by a coating of acicular, needle-like yellow crystals, grouped in radial aggregates (Fig. 4a). During sample selection tasks, it was observed that these coatings also occur on grains of other mineral nature, such as iron oxy-hydroxides or quartz, frequently associated with surface adhered clays (Fig. 4b). The low abundance of such materials made it impossible to determine accurately their mineralogical identity by means of conventional powder XRD techniques. However, some chemical informaton is available in the following section conceming these coatings, including a reasonable speculation on the possibility of phosphuranylite occurrence.

\subsection{Mineral chemical composition and textural features}

\subsubsection{EMP analyses}

Table 1 displays the chemical composition of eight mineral individuals, representative of the selected uranyl phosphates, obtained by EMP quantitative analyses. The displayed results conceming analyses (1) to (6) are normalized to ideal $15 \mathrm{wt} . \% \mathrm{H}_{2} \mathrm{O}$ and the corresponding atomic fractions are based on twelve equivalent oxygen atoms per unit formula.

The analyses (1) to (5) in Table 1 reflect compositions very close to the pure end-members of the metatorbernite-metauranocircite joint. In fact, most of the studied individuals have nearly-stoichiometric $\mathrm{Cu}\left(\mathrm{UO}_{2}\right)_{2}\left(\mathrm{PO}_{4}\right)_{2} \cdot n \mathrm{H}_{2} \mathrm{O}$ and $\mathrm{Ba}\left(\mathrm{UO}_{2}\right)_{2}\left(\mathrm{PO}_{4}\right)_{2} \cdot n \mathrm{H}_{2} \mathrm{O}$ compositions, even though chemical variations occur, involving some degree of deviation from the ideal stoichiometries (analyses (6) to (8)). Analysis (6) reveals a composition where $\mathrm{Cu}$ and $\mathrm{Ba}$ occur with 0.8 and 0.1 atomic fractions, respectively, corresponding to a $\mathrm{Cu}_{x} \mathrm{Ba}_{1-x}\left(\mathrm{UO}_{2}\right)_{2}\left(\mathrm{PO}_{4}\right)_{2} \cdot n \mathrm{H}_{2} \mathrm{O}$ intermediate solid solution. Analyses (7) and (8), on the other hand, concern solids enriched in $U$ and depleted in both divalent cations, a chemical content comparable to the analyses reported by Ross (1955) with respect to chemikovite, $\left(\mathrm{H}_{3} \mathrm{O}\right)_{2}\left(\mathrm{UO}_{2}\right)_{2}\left(\mathrm{PO}_{4}\right)_{2} \cdot 8 \mathrm{H}_{2} \mathrm{O}$. The occurrence of interlayer cation depletion during EMP analysis is also known to affect intensely uranyl phosphates, especially torbernite, in response to both vacuum and high beam energy (Stubbs et al., 2007). However, since cation depleted phases coexist with nearly stoichiometric uranyl phosphates in the same samples, such analytically induced cation removal process can hardly be a source for the encountered compositions. Summing up, in the present study the analyzed uranyl phosphates are mostly nearly
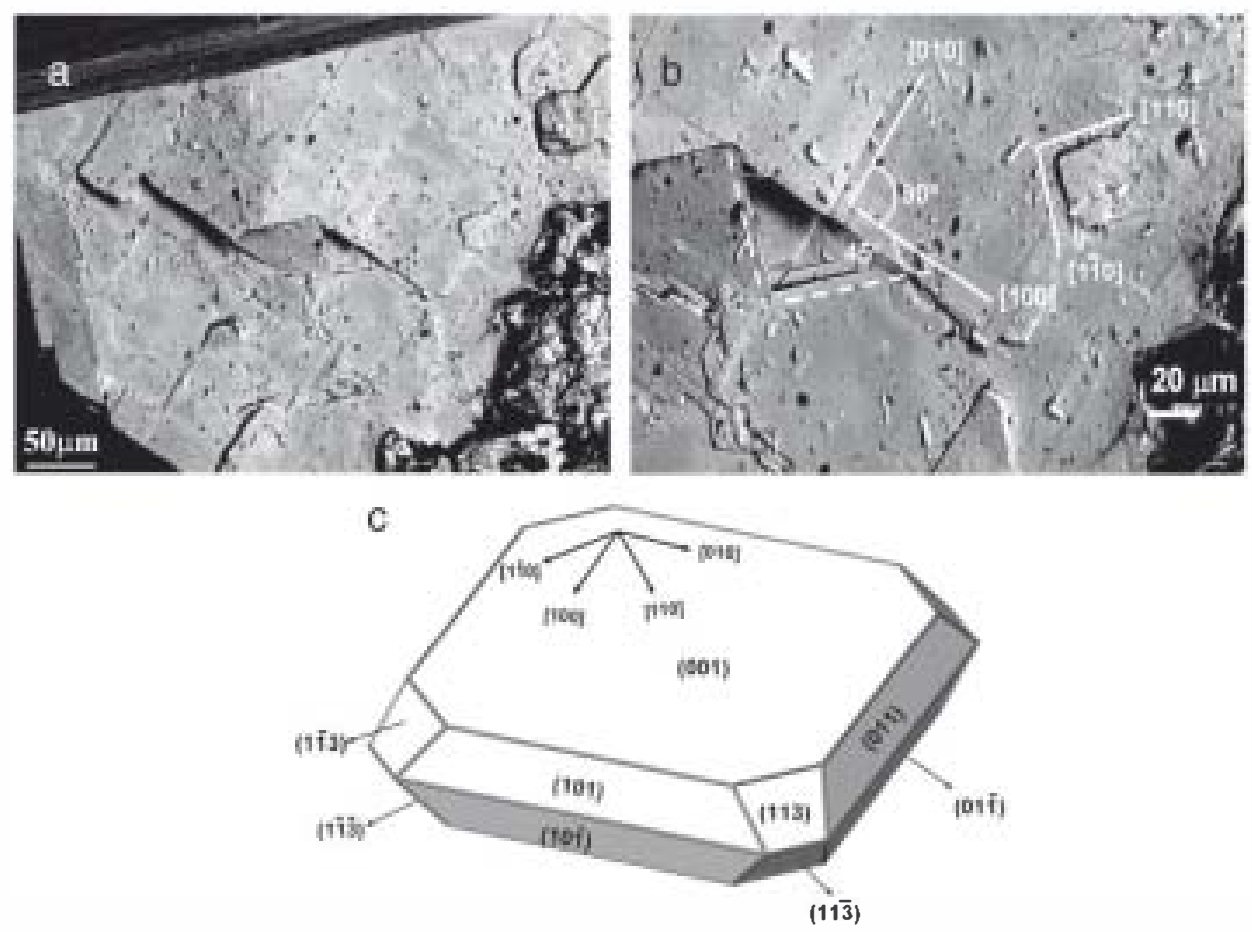

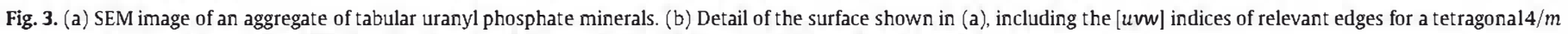
symmetry. (c) Simulation (using SHAPE) of the hypothetical forms $\{001\},\{011\}$ and $\{113\}$, by order of decreasing importance. 

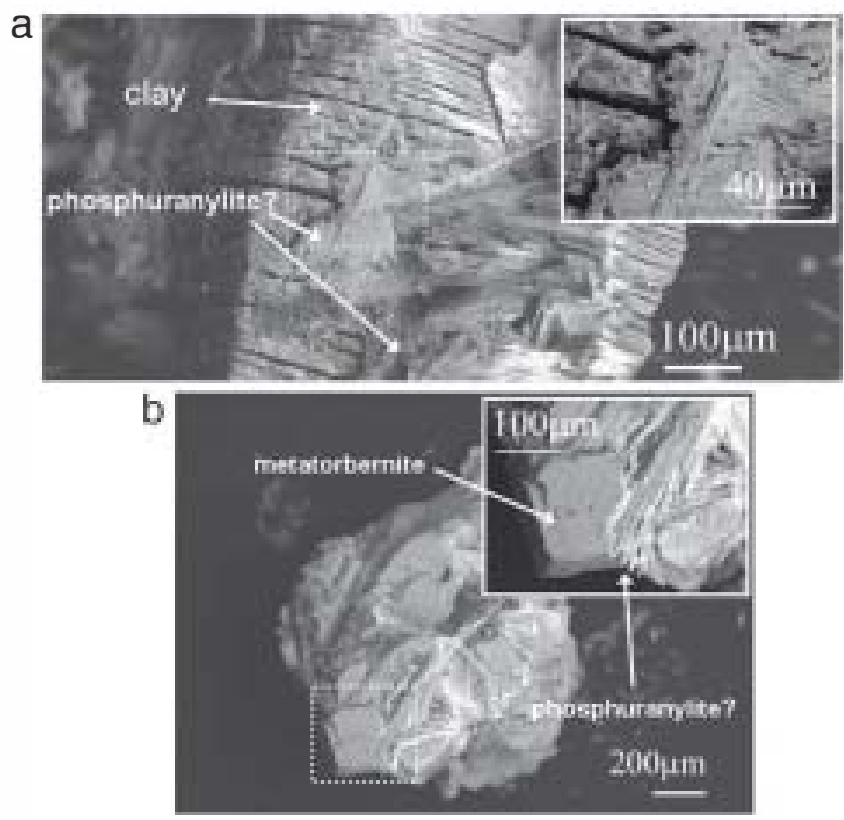

Fig. 4. SEM images of the rare radial aggregates of acicular uranyl phosphates, overgrown on (a) clay and (b) metatorbernite.

stoichiomeric $\mathrm{Cu} / \mathrm{Ba}\left(\mathrm{UO}_{2}\right)_{2}\left(\mathrm{PO}_{4}\right)_{2} \cdot n \mathrm{H}_{2} \mathrm{O}$ phases, with minor occurrences of intermediate $\left(\mathrm{Cu}^{2+}, \mathrm{Ba}^{2+}\right)\left(\mathrm{UO}_{2}\right)_{2}\left(\mathrm{PO}_{4}\right)_{2} \cdot n \mathrm{H}_{2} \mathrm{O}$ and $\left(2 \mathrm{H}_{3} \mathrm{O}^{+}\right.$, $\left.\mathrm{Cu}^{2+} / \mathrm{Ba}^{2+}\right)\left(\mathrm{UO}_{2}\right)_{2}\left(\mathrm{PO}_{4}\right)_{2} \cdot n \mathrm{H}_{2} \mathrm{O}$ compositions.

These findings are in agreement with the XRD results and confirm the presence of a mechanical mixture of phases with similar structures in the analyzed samples. Even the possible occurrence of divalent cation-deficient phases does not represent a source of deep crystallographic contrast, since chemikovite is nearly isostuctural with metatorbemite, with resulting very similar powder diffraction patterns. Moreover, the Ba-rich member encountered in EMP studies may not correspond to metauranocircite, but to a tetragonal Ba-bearing hydrated uranyl phosphate, isostructural with metatorbernite. The occurrence of a similar type of phases has been previously reported for the Coles Hill deposit by Jerden and Sinha (2003) and Jerden et al. (2003); mentioned as "barium meta-autunites".

The analyses performed to the rare radial aggregates of acicular crystals, usually present as coatings, produced less reliable results, since these phases have very low resistance to the electron beam and are finely intermixed with other materials (quartz, clay, oxy-hydroxides, etc.). An approximate composition for these materials yields $\sim 2 \% \mathrm{CaO}$, $\sim 75 \% \mathrm{UO}_{3}$ and $\sim 12 \% \mathrm{P}_{2} \mathrm{O}_{5}$ wt.\%; rather consistent results with published analyses of phosphuranylite (Anthony et al., 1990). However, since

\section{Table 1}

Chemical analyses of uranyl phosphates from Tarabau outcrop. The results of analyses (1) to (6) are normalized to ideal $15 \mathrm{wt} . \% \mathrm{H}_{2} \mathrm{O}$ and the atomic fractions were determined according to 12 oxygen per unit formula, ignoring the interlayer $\mathrm{H}_{2} \mathrm{O}$. Relative standard deviations for raw data, derived from counting statistics are $0.3 \%$ for $\mathrm{CaO}$, $0.4 \%$ for $\mathrm{P}_{2} \mathrm{O}_{5}, 0.5 \%$ for $\mathrm{CuO}, 1.8 \%$ for $\mathrm{UO}_{3},<1 \%$ for $\mathrm{MnO}, 0.2 \%$ for $\mathrm{Na}_{2} \mathrm{O}, 0.3 \%$ for $\mathrm{TiO}_{2}$, $1 \%$ for $\mathrm{BaO}, 1.2 \%$ for $\mathrm{ZnO}, 0.8 \%$ for $\mathrm{Al}_{2} \mathrm{O}_{3}, 0.3 \%$ for $\mathrm{SiO}_{2}, 0.4 \%$ for $\mathrm{Fe}_{2} \mathrm{O}_{3},<1 \%$ for $\mathrm{SO}_{3}$, $0.5 \%$ for $\mathrm{MgO}, 0.1 \%$ for $\mathrm{Cr}_{2} \mathrm{O}_{3}$ and $0.4 \%$ for $\mathrm{V}_{2} \mathrm{O}_{3}$.

\begin{tabular}{lrlllrrll}
\hline & $(1)$ & $(2)$ & $(3)$ & $(4)$ & \multicolumn{1}{c}{$(5)$} & $(6)$ & $(7)$ & $(8)$ \\
\hline $\mathrm{UO}_{3}$ & 61.1 & 62.3 & 61.5 & 58.8 & 57.9 & 62.8 & 69.1 & 70.5 \\
$\mathrm{P}_{2} \mathrm{O}_{5}$ & 14.1 & 13.9 & 13.7 & 12.7 & 12.2 & 14.1 & 13.8 & 13.6 \\
$\mathrm{CuO}$ & 8.6 & 7.1 & 6.9 & $<0.1$ & 0.3 & 6.8 & 1.2 & 0.5 \\
$\mathrm{BaO}$ & 0.2 & $<0.1$ & $<0.1$ & 11.6 & 12.2 & 1.0 & 3.3 & 1.7 \\
Total & 83.9 & 83.3 & 82.1 & 83.1 & 82.2 & 84.7 & 87.3 & 86.3 \\
$\mathrm{U}$ & 2.1 & 2.1 & 2.1 & 2.2 & 2.2 & 2.1 & - & - \\
$\mathrm{P}$ & 1.9 & 1.9 & 1.9 & 1.9 & 1.8 & 1.9 & $*$ & - \\
$\mathrm{Cu}$ & 1.0 & 0.9 & 0.9 & - & $<0.1$ & 0.8 & - & - \\
$\mathrm{Ba}$ & $<0.1$ & & - & 0.8 & 0.9 & 0.1 & & - \\
\hline
\end{tabular}

potassium was not detected, there is still the doubt of whether this phase corresponds to a K-deficient phosphuranylite or any other uranyl phosphate.

\subsubsection{Textural features}

Fig. Sa depicts a secondary electrons' SEM image of a polished section, containing selected aggregates of uranyl phosphate crystals, where the subparallel groups of fractures related to the (001) cleavage planes of metatorbernite are easily observed. Yet, such aggregates are sometimes inhomogeneous, as can be observed in Fig. 5b, which is an enhanced BSE image focusing a zone of the aggregate shown in Fig. 5a. The brighter area corresponds to Ba-rich compositions, whereas the smaller, dark-contrasted area involves Cu-bearing compositions. It is worth noting the sharp contact between the two zones, subparallel to the cleavage fractures, involving an abrupt compositional gradient. A circular "scour" caused by the electron beam during quantitative analyses is visible in the central region of the dark zone (Fig. Sb).

Another important textural occurrence concerns the association between the studied uranyl phosphates and oxide-hydroxide materials. Fig. 6a displays a section of a quartz vein hosting uranyl phosphates, which correspond to the brighter materials, surrounded by Al, Fe oxy-hydroxides. A closer inspection, shown in Fig. 6b, reveals an exremely irregular contact between these last phases and the uranyl phosphate minerals, which present "corroded" borders. Moreover, a textural contrast within the oxy-hydroxide materials also occurs, since there is a narrow rim roughly following the uranyl phosphate outline, individualized from the bulk $\mathrm{Al}$, Fe oxy-hydroxide. EDS semiquantitative analyses revealed that the $\mathrm{Al}$, Fe oxy-hydroxides also contain phosphorus and traces of uranium detected by systematic counting statistics above background obtained along compositional profiles.

\section{Discussion}

\subsection{Mineral replacement in the copper-barium uranyl phosphate system}

The textural relationships depicted in Fig. 5 are frequently encountered involving sharp boundaries between $\mathrm{Cu}$ and Ba-rich uranyl phosphate minerals, being the Ba-rich occurrences often surrounding Cu-bearing domains. In order to unravel the equilibrium mechanisms behind these petrographic features, EMP X-ray elemental mapping has been performed across boundaries separating uranyl phosphates, as shown in Fig. 7. In fact, as can be observed in Fig. 7c, a narrow zone of Ba enrichment exists parallel to the mineral interface, within the Cu-bearing uranyl phosphate, which marks a reaction front. The solubility relationships between the involved phases cannot be accurately

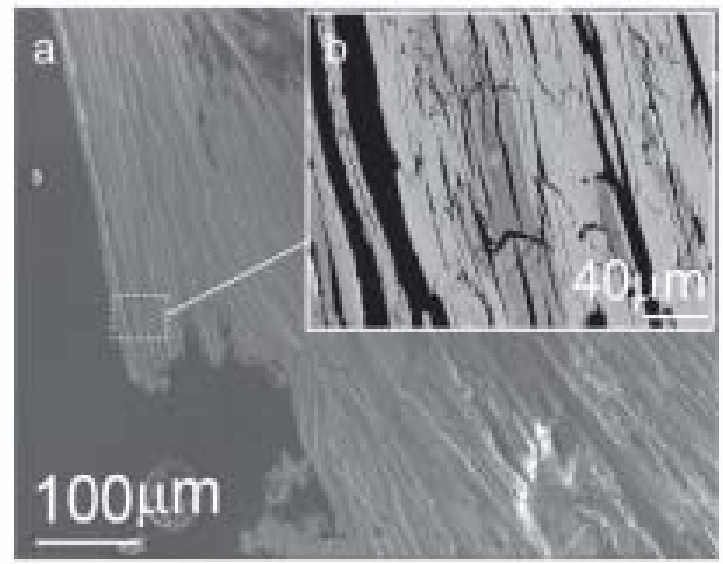

Fig. 5. (a) Secondary electrons SEM image of a uranyl phosphate aggregate in cross section. (b) Detail in BSE mode of the section shown in (a). Bright contrast corresponds to Ba-rich zones and dark contrast to $\mathrm{Cu}$-rich areas. A circular "scour" can be observed in the dark zone, due to the incident electron beam during microanalysis. 


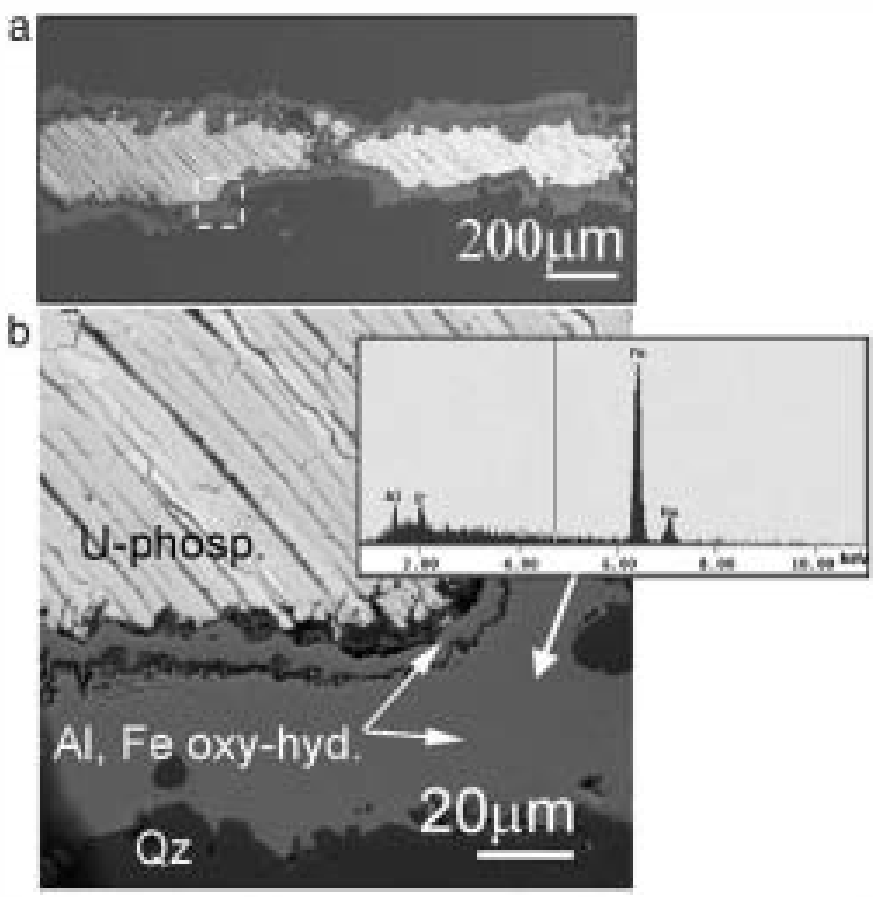

Fig. 6. (a) SEM micrograph showing the overall aspect of a quartz vein, hosting uranyl phosphate materials coated with aluminium/iron oxy-hydroxide, in cross section. (b) Enhancement of the zone delimited in (a) by a dashed rectangle, including phase labels $(\mathrm{Qz}=$ quartz; Al, Fe oxy-hyd. = iron oxy-hydroxides; U-phos. = uranyl phosphate. $)$ and a representative EDS profile.

assessed due to the lack of standard solubility information relative to "tetragonal" Ba-rich uranyl phosphate. However, a comparison between reported Ksp values for metatorbemite (Vochten et al., 1981;
Clara et al., 1985; Ilton et al., 2010) and metauranocircite-II (Vochten et al., 1992; Wojciechowsli et al., 2003) reveals much lower solubility of the Ba-bearing phase in all cases. Such determinations, point toward Ba-uranyl phosphate as being the most stable phase in $\mathrm{Cu} / \mathrm{Ba}$ bearing aqueous media at supergene conditions. Thus the textures with reaction fronts depicted in Figs. 5 and 7 clearly illus the replacement of Cu-rich uranyl phosphate by the less soluble Ba-rich equivalent. Since we are dealing with low temperature minerals which precipitate directly from supersaturated aqueous solutions, dissolution and precipitation should be the principal driving mechanisms of thermodynamic reequilibration (Putnis, 2009). A possible overall replacement reaction can be written as:

$$
\mathrm{Cu}\left(\mathrm{UO}_{2}\right)_{2}\left(\mathrm{PO}_{4}\right)_{2} \cdot n \mathrm{H}_{2} \mathrm{O}+\mathrm{Ba}^{2+} \rightarrow \mathrm{Ba}\left(\mathrm{UO}_{2}\right)_{2}\left(\mathrm{PO}_{4}\right)_{2} \cdot \mathrm{nH}_{2} \mathrm{O}+\mathrm{Cu}^{2+}
$$

This type of mineral replacements affecting uranyl phosphates is known to take place in nature. For instance, Dill et al. (2010) describe the occurrence of autunite from Flössenburg, Germany, $\mathrm{Ca}\left(\mathrm{UO}_{2}\right)_{2}\left(\mathrm{PO}_{4}\right)_{2} \cdot 10-12 \mathrm{H}_{2} \mathrm{O}$, with a core of torbernite, as being epitactically intergrown. Such replacement relationship consists of a pseudomorphism where there is a coincidence between parent and product phase crystal forms, considering the pseudo-tetragonal morphology of metauranocircite. Another example of replacement occurring between uranyl phosphates is the one found at the Koongarra site, Australia, by Murakami et al. (1997), where sklodowskite, $\left(\mathrm{H}_{3} \mathrm{O}\right)_{2} \mathrm{Mg}\left(\mathrm{UO}_{2}\right)_{2}\left(\mathrm{PO}_{4}\right)_{2} \cdot 4 \mathrm{H}_{2} \mathrm{O}$, is pseudomorphically replaced by saléeite.

The X-ray mapping relative to uranium, illustrated in Fig. 8, reveals some chemical inhomogeneity affecting both types of uranyl phosphates shown in Fig. 7, especially the Cu-rich. A closer look discloses zones enriched in $U$ subparallel to the cleavage fractures. Such spatial pattern is comparable to the X-ray signal regarding $\mathrm{Cu}$, which is weak except in few narrow areas, also subparallel to the

\section{a}

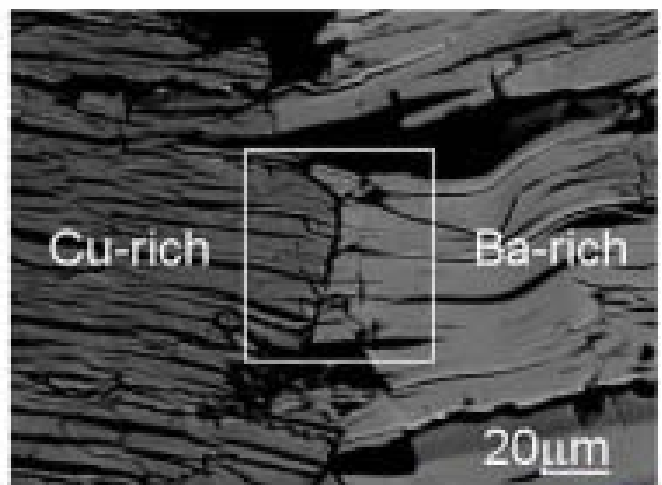

High counts
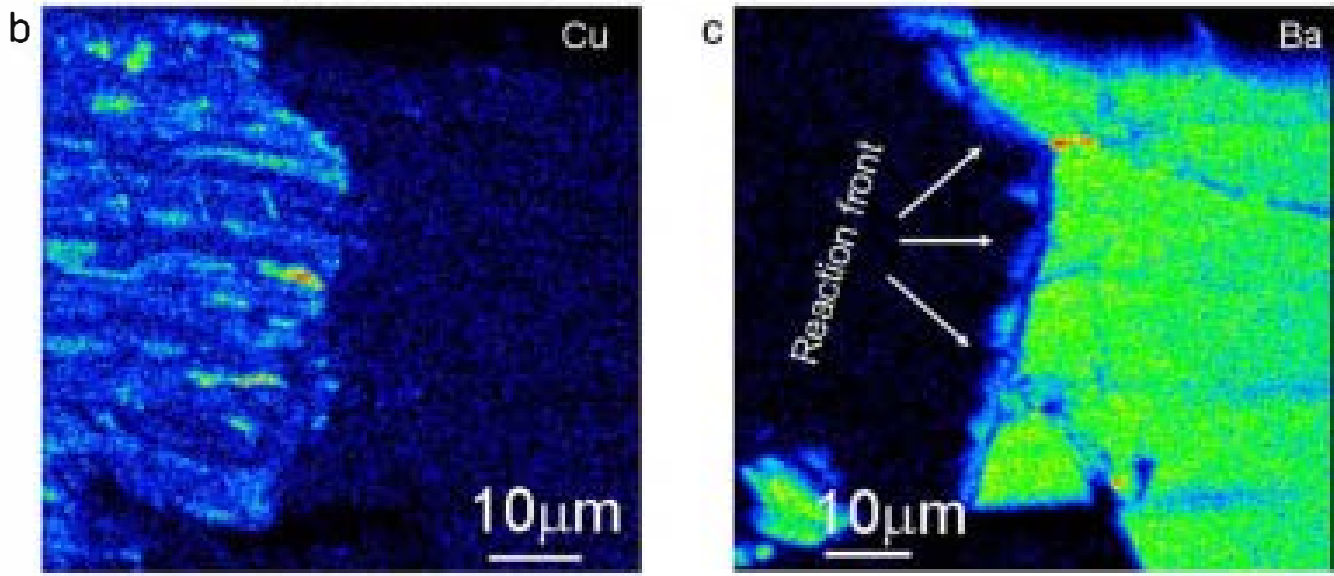

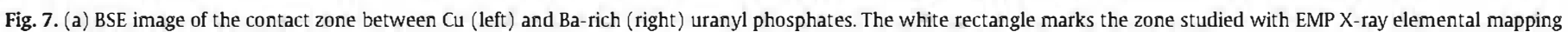
concerning (b) copper and (c) barium content. 
cleavage fractures. Quantitative analyses performed within $\mathrm{Cu}$-rich uranyl phosphate yield compositions $\mathrm{Cu}_{0.7-0.8}\left(\mathrm{UO}_{2}\right)_{2.1-2.2}\left(\mathrm{PO}_{4}\right)_{1.9} \cdot n \mathrm{H}_{2} \mathrm{O}$, confirming the mapped variations in chemical content. Thus, the depletion in $\mathrm{Cu}^{2+}$ involves a relative enrichment in $U$ and $P$, since the composition retains a nearly $1: 1 \mathrm{U}: \mathrm{P}$ ratio. A much lesser pronounced variation with respect to $U$ is found within the Ba-rich domains, in agreement with the homogeneous pattern shown in Fig. 7c concerning Ba spatial distribution. However, a striking feature displayed in Fig. 8 is the continuity of the chemical inhomogeneity across domain boundary, from $\mathrm{Cu}$ to Ba-rich uranyl-phosphates, in spite of the sharp contrast decrease within Ba-rich materials. The difference in cation depletion levels is a reflex of the different bonding characteristics of the hydrated interlayer in both phases. The observations made with X-ray elemental mapping point toward the occurrence of selective divalent cation removal processes affecting uranyl phosphate phases, superimposed to coupled dissolution-precipitation reactions. A possible mechanism supported by our quantitative results is the advent of ion exchange-assisted transformation of divalent cation-uranyl phosphate into chernikovite, (Vochten et al., 1984; Vochten, 1990; Vochten et al., 1992) according to:

$$
\mathrm{X}\left(\mathrm{UO}_{2}\right)_{2}\left(\mathrm{FO}_{4}\right)_{2} \cdot \mathrm{nH}_{2} \mathrm{O}+2 \mathrm{H}_{4} \mathrm{O}^{4}-\left(\mathrm{H}_{4} \mathrm{O}\right)_{2}\left(\mathrm{OO}_{2}\right)_{2}\left(\mathrm{PO}_{4}\right)_{2} \cdot \mathrm{nH}_{3} \mathrm{O}+\mathrm{X}^{2+}
$$

where $X$ is a divalent cation, in the present case $\mathrm{Cu}^{2+}$ or $\mathrm{Ba}^{2+}$. Such reaction does not involve a change in crystal morphology, since only the cation of the hydrated layer is affected. Vochten et al. (1992) explain the ransformation of chemikovite to metauranocircite II as a diffusioncontrolled process of the exchanging ions between the $\left[\mathrm{UO}_{2} \mathrm{PO}_{4}\right]_{n}^{\text {n- }}$ negatively charged layers. Such model is very similar to the one proposed by Casey et al. (1993) concerning the formation of leached layers in chain silicates, where a diffusive ransport across the reacted rim is also invoked. Nevertheless, since we are dealing with supergenic minerals which form at low temperature, diffusion processes seem unlikely to play an important role in exchange reactions, because they involve unfavourable kinetics toward other reactive paths. An altemative mechanism for exchanging cations effectively across a reacted rim is the formation of porosity as a result of the exchange itself, allowing the fluid to reach the reaction front. Considering standard data, the transformation of metatorbernite (Locock and Burns, 2003) and metauranocircite I (Locock et al., 2005), to chemikovite (Ross, 1955) involves a

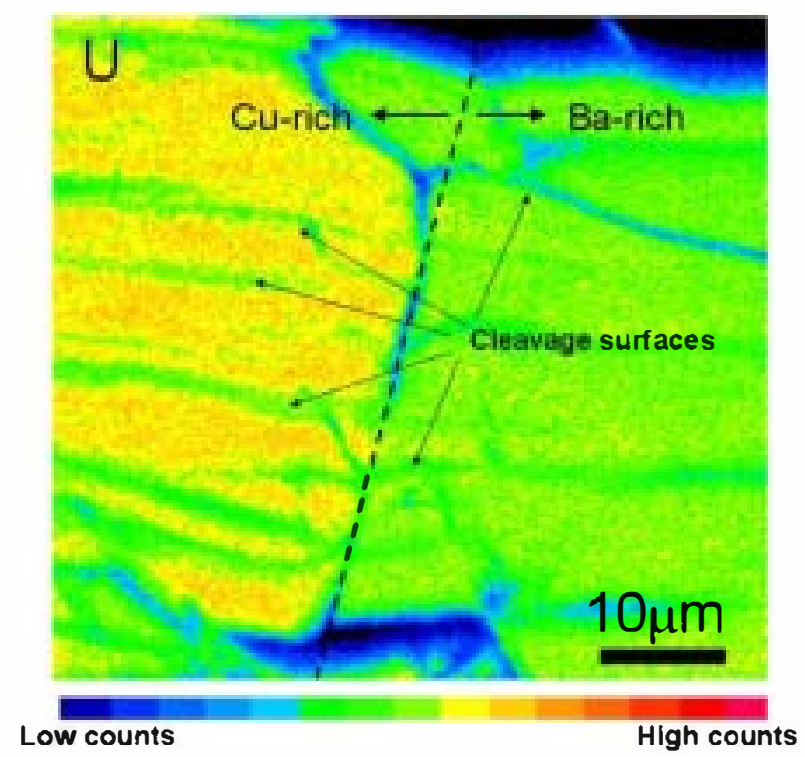

Fig. 8. EMP uranium X-ray elemental mapping of the boundary zone displayed in Fig. $6 \mathrm{~b}$ and $\mathrm{c}$. The dashed line marks the boundary between $\mathrm{Cu}$ and Ba-rich uranyl phosphates decrease in molar volume of $\sim 47 \%$ and $\sim 48 \%$ respectively, which supports the possibility of generating porosity during the pseudomorphic exchange reaction. The occurrence of porous layers as a result of mineral replacement reactions is common in cases of incongruent dissolution , such as silicate minerals and glasses (e.g. Petit et al., 1990; Casey et al, 1993; Hellmann et al., 2003), and pseudomorphic replacements by coupled dissolution-precipitation reactions (Kasioptas et al., 2008). It is worth noting that the completeness of reaction (2) requires fairly acidic conditions, and the moderately acid character of granitic waters could lead to slower and only partial exchange between cations and protons, thus explaining the measured cation-depleted intermediate compositions. Fig. 9 displays a schematic representation summing up the replacement processes affecting the studied uranyl phosphate phases: a) dissolution-reprecipitation of divalent cation-bearing uranyl phosphates, with the development of replacement rims of the less soluble phase; and b) cation exchange reactions, generating porous leached layers, depleted in the divalent cation.

\subsection{Replacement of uranyl phosphates by oxy-hydroxides}

The texture shown in Fig. 6b implies a mineral replacement reaction, where Al-Fe oxy-hydroxide is substituting a uranyl phosphate phase. Such statement is supported by the observation of "corroded" reactive borders in the uranyl phosphate, a clear sign of mineral dissolution, contacting with a rim of oxy-hydroxide materials defining its outer contour. This individualized rim should correspond to lowcrystallinity oxide phases, which readily precipitate as the uranyl phosphate dissolves, and later evolve to aged, more crystalline oxides. As the dissolution/precipitation reaction continues and the oxide rim progresses inward the uranyl phosphate, complete mineral replacement may be achieved, depending on kinetic/thermodynamic constraints. Additionally to textural evidences for dissolution/precipitation reactions affecting these phases, the occurrence of $\mathrm{P}$ - and occasionally $\mathrm{U}$ - in the oxy-hydroxide compositions, also suggests sorption of uranyl phosphate-derived species onto co-precipitated Fe phases, a process known to occur in these environments (e.g. Bruno et al., 1995; Payne et al., 1996; Ohnuki etal., 1997; Duffet al., 2002). The close geochemical interdependence of uranyl, phosphate and iron may also influence the fate of aqueous REE concentrations, as demonstrated by Stille et al. (2003). Fig. 10 depicts schematically the reaction path suggested by the textural and chemical information acquired in the present work, concerning uranyl phosphate and oxy-hydroxide phases: 1) uranyl phosphate precipitation, 2) dissolution of uranyl phosphate coupled with oxy-hydroxide precipitation containing sorbed $U$ and $P$, forming a replacement rim, 3) increase in crystallinity of oxy-hydroxides, with possible desorption of $U$ and $P$.

The observed mineral replacement reaction is interpreted inversely in the scientific literature (Murakami et al., 1997; Sato et al., 1997; Murakami et al., 2005) because replacement textures are not always evident, especially in advanced reaction stages when the original phase is nearly or completely absent (Putnis, 2009). That seems to be the case described by Murakami et al. (2005), where the occurrence of metatorbemite suctural lattice fringes within goethite is attributed to uranyl phosphate precipitation, following Ostwald ripening transformation of ferrihydrite to goethite. However, the possibility that such metatorbemite nano-domains may correspond to relics from a replacement reaction is never considered. Moreover, it is seems unlikely that the event of nucleation and growth occurs within the structural premises of goethite, as shown in high resolution transmission electron microscope images.

Other cases, where the replacement reaction is quite obvious can be found in the literature. For instance, Sato et al. (1997) show an image of a Fe-nodule clearly pseudomorphically replacing a previously existent uranyl phosphate. The depicted sharp outline corresponding to relic edges, and the relic core in the nodule, are typical signs of mineral replacement textures. Along the nodule borders, relics of the 


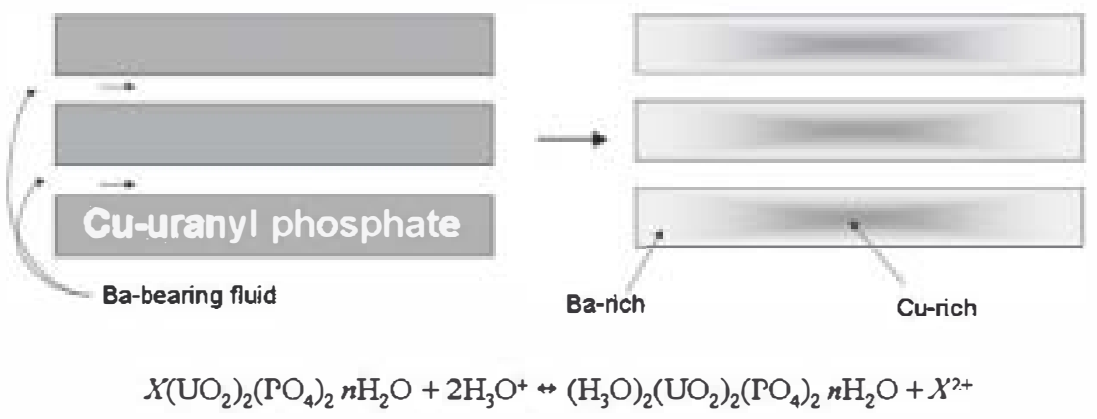

b

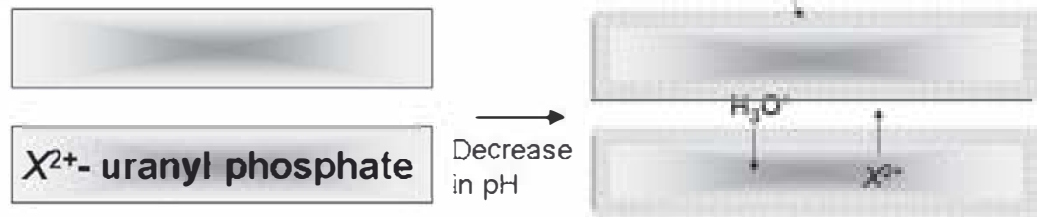

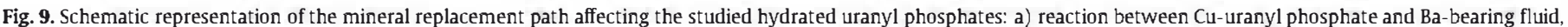

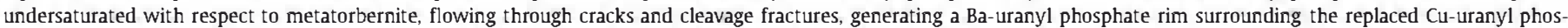

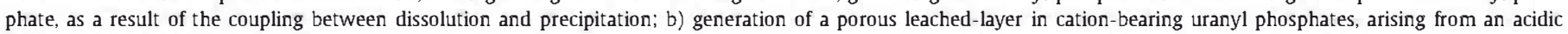
cation-exchange reaction

parental crystal are also evident in BSE contrast and confirmed by the shown X-ray map. A replacement relationship is, however, the opposite to the explanation offered in Sato's work. Another striking feature in Sato and co-authors' results is the positive correlation between $\mathrm{Cu}-\mathrm{U} /$ Cu-P nodule content, consistent with the presence of metatorbemite relics within the replacement assemblage. Nonetheless, a speculation is produced about the possible precipitation of metatorbernite nanoparticles, while simultaneously struggling with evidence for solution undersaturation with respect to both metatorbernite and saléeite. Such consideration is justified by prior experimental and theoretical evidences for surface induced precipitation, even when the bulk solution is undersaturated (James and Healy, 1972a,b). However, all textural relationships and geochemical data point toward $\mathrm{Cu}, \mathrm{U}$ and $\mathrm{P}$ sorption onto the Fe-nodules during metatorbernite replacement, as the correct reactive pathway, also consistent with the bulk solution undersaturation with respect to uranyl phosphates. The exact environmental conditions

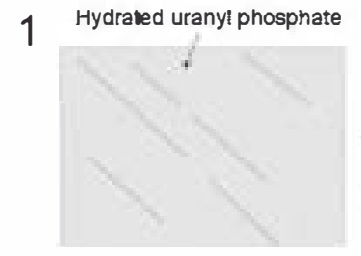

3

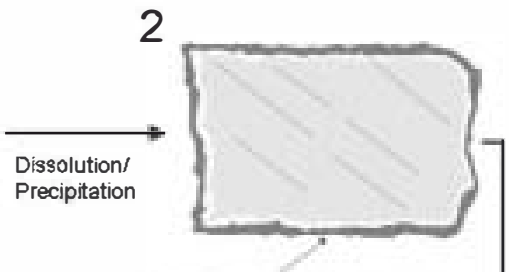

Amorphous Fe oxy-hydroxide + sorbed $U, P$

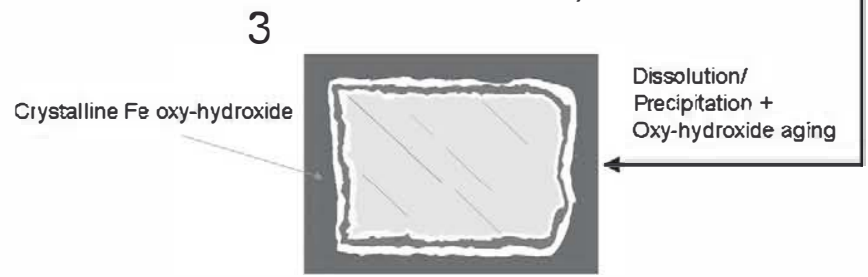

Fig. 10. Schematic representation of the replacement reaction of uranyl phosphate by oxy-hydroxide materials: 1) precipitation of uranyl phosphates, 2) dissolution of uranyl phosphate materials coupled with the precipitation of a low-crystallinity oxyhydroxide rim, including sorbed $U$ and $P$ species and 3 ) replacement progresses inwards the uranyl phosphate domain. The previously formed oxy-hydroxide materials age to more crystalline phases, triggering possible desorption of $U$ and $P$ species. prevailing during the development of such substitutional reactions, however, remain unknown.

The results here presented concerning the mineralogical relationships between Fe oxy-hydroxides and uranyl phosphates reveal that simultaneous equilibrium with respect to both phases may not be achieved during $U$ transport in oxidizing environments, and the previously proposed models for phase equilibria involving uranyl phosphates need to be revised.

\section{Conclusions}

The results obtained in the present work allowed unravelling reequilibration reactions affecting naturally occurring $\mathrm{Cu}$ and Ba uranyl phosphates. Such reactive paths involve the replacement of $\mathrm{Cu}$-bearing by Ba-bearing uranyl phosphates, cation-bearing uranyl phosphate by cation-depleted uranyl phosphate and cation-bearing uranyl phosphate by Fe, Al oxy-hydroxides. However, the studied textural features point toward two different mechanisms of mineral replacement, with superimposed expressions. On one hand, the replacement of $\mathrm{Cu}$ by Ba uranyl phosphate phases, and these last by oxy-hydroxides, takes place by coupled dissolution-precipitation reactions. On the other hand, cation depletion affecting uranyl phosphates occurs by a cation exchange process, possibly giving rise to an increase in mineral porosity.

The observations here presented bring up the need of revising the widely accepted models for $\mathrm{U}(\mathrm{VI})$ reactive paths in supergenic oxidizing conditions, especially in the terminal stages of its aqueous transport, since our findings show that uranyl phosphate/oxide mineral equilibria relationships may have been misinterpreted in the past. Future research should focus on thermodynamic and kinetic constrains of the approached mineral replacement relationships and their implications to the fate of $\mathrm{U}(\mathrm{VI})$ in the environment.

\section{Acknowledgments}

This research project was partly supported by the Department of Geology of the University of Lisbon and included in the cooperative actions "Acções Integradas Luso-Espanholas 2010", in partnership with the Department of Crystallography and Mineralogy of the University Complutense of Madrid jointly funded by the CRUP, Portugal and the Ministerio de Ciencia e Innovación, Spain (reference AIB2010PT- 
00282). André Jorge Pinto acknowledges the support obtained from the post-doctoral scholarship, funded by the FCT ("Fundação para a Ciência e a Tecnologia", reference SFRH/BPD/65314/2009). The authors also acknowledge the financial support provided by the Ministerio de Ciencia e Innovación, Spain (Project CGL2010-20134-C02-01). Finally, we thank two anonymous reviewers whose constructive comments helped in improving the overall quality of the present work.

\section{References}

Airey, P.L, 1986. Radionuclide migration around uranium ore bodies in the Alligator Rivers Region of the Northern Territory of Australia: analogue of radioactive waste repositories, a review. Chemical Geology 55, 255-268.

Anthony, J.W., Bideaux, R.A., Bladh, K.W., Nichols, M.C., 1990. Handbook of mineralogy. Mineral Data Publishing, Tucson Arizona, USA, by Permission of the Mineralogical Society of America.

Bargar,J.R, Bernier-Latmani, R., Giammar, D.E., Tebo, B.M., 2008. Biogenic uraninite nanoparticles and their importance for uranium remediation. Elements 4, 407-4012.

Bostic, W.D., Stevenson, R.J., Jarabek, R.J., Conca, J.L., 2000. Use of apatite and bone char for the removal of soluble radionuclides in authentic and simulated DOE groundwater. Advances in Environmental Research 3, 488-498.

Bruno,J., De Pablo,J., Duro, L., Figuerola, E., 1995. Experimental study and modelling of the $\mathrm{U}(\mathrm{Vl})-\mathrm{Fe}(\mathrm{OH})_{3}$ surface precipitation/coprecipitation equilibria. Geochimica et Cosmochimica Acta 59, 4113-4123.

Burns, P.C. 1999. The crystal chemistry of uranium. In: Burns, P.C., Finch, R. (Eds.), Uranium: Mineralogy, Geochemistry and the Environment. Reviews in Mineralogy, 38. The Mineralogical Society of America, Washington DC, pp. 23-90.

Casey, W.H., Westrich, H.R. Banfield,J.F., Ferruzri, G. Arnold, G.W., 1993. Leaching and reconstruction of the surfaces of dissolving chain-silicate minerals. Nature 366. 253-256.

Clara, M., Magalhães, F., De Jesus, J.D.P., Williams, PA., 1985. The chemistıy of uranium dispersion in groundwaters at the Pinhal-do-Souto mine, Portugal. Inorganica Chimica Acta 109, 71-78.

Demartin, F., Diella, V.. Donzelli, S., Gramaccioli, C.M., Pilati, T., 1991. The importance of accurate crystal structure determination of uranium minerals. I. phosphuranylite $\mathrm{KCa}\left(\mathrm{H}_{3} \mathrm{O}\right)_{3}\left(\mathrm{UO}_{2}\right)_{7}\left(\mathrm{PO}_{4}\right)_{4} \mathrm{O}_{4} \cdot 8 \mathrm{H}_{2} \mathrm{O}$. Acta Crystallographica $\mathrm{B} 47,439-446$.

Dill, H.G., Gerdes, A, Weber, B., 2010. Age and mineralogy of supergene uranium minerals - tools to unravel geomorphological and palaeohydrological processes in granitic terrains (Bohemian Massif, SE Germany). Geomorphology 117, 44-65

Duff, M.C. Coughlin, J.U., Hunter, D.B., 2002. Uranium co-precipitation with iron oxide minerals. Geochimica et Cosmochimica Acta 66, 3533-3547.

Ewing, R.C., 2006a. The nuclear fuel cycle: a role for mineralogy and geochemistry. Elements 2, 331-334.

Ewing, R.C. (Ed.), 2006b. The nuclear fuel cycle - environmental aspects: Elements, 2, 6, pp. 321-392.

Fernández-González, A., Andara, A., Prieto, M., 2007. Mixing properties and crystallization behaviour of the scheelite-powellite solid solution. Crystal Growth and Design 7. 545-552.

Finch, R., Murakami, T., 1999. Systematics and paragenesis of uranium minerals. In: Burns, P.C. Finch, R. (Eds.), Uranium: Mineralogy, Geochemistry and the Environment. Reviews in Mineralogy, 38. The Mineralogical Society of America, Washington DC, pp. 91-179.

Fuller, C.C., Bargar, J.R., Davis, J.A., Piana, M.J., 2002. Mechanisms of uranium interactions with hydroxyapatite: implications for groundwater remediation. Environmental Science and Technology 36, 158-165.

González Menéndez, L.G.. Azor, A., Rubio Ordóñez, A.R. Sánchez-Almazo, I., 2011. The metamorphic aureole of the Nisa-Albuquerque batholith (SW Iberia): implications for deep structure and emplacement mode. International Journal of Earth Sciences 100, 1533-1550.

Hellmann, R., Penisson, J.-M., Hervig, R.L, Thomassin, J.-H., Abrioux, M.-F., 2003. An EFIEM/HRTEM high resolution study of the near surface labradorite feldspar altered at acid pH: evidence for interfacial dissolution-reprecipitation. Physics and Chemistry of Minerals 30, 192-197.

Hogarth, D.D., Nuffield, E.W., 1954. Studies of radioactive compounds: VII - phosphuranylite and dewindtite. American Mineralogist 39, 444-447.

Ilton, E.S., Zachara, J.M., Moore, D.A., McKinley, J.P., Eckberg, A.D., Cahill, C.L., Felmy, A.R., 2010. Dissolution study of metatorbemite: themodynamic properties and the effect of $\mathrm{pH}$ and phosphate. Environmental Science and Technology 44, 7521-7526.

Isobe, H., Murakami, T., Ewing, R.C., 1992.Alteration of uranium minerals in the Koongarra deposit, Australia: unweathered zone. Joumal of Nuclear Materials 190, 174-187.

Isobe, H., Ewing, R.C., Murakami, T., 1994. Formation of secondary uranium minerals in the Koongarra deposit, Australia. Materials Research Society Symposium Proceedings $333,653-660$.

James, R.O., Healy, T.W., 1972a. Adsorption of hydrolyzable metal ions at the oxidewater interface. I. $\mathrm{Co}(\mathrm{II})$ adsorption on $\mathrm{SiO}_{2}$ and $\mathrm{TiO}_{2}$ as model systems. Journal of Colloid and Interface Science 40,42-52.

James, R.O., Healy, T.W., 1972b. Adsorption of hydrolysable metal ions at the oxidewater interface. III. A thermodynamic model of adsorption. Journal of Colloid and Interf ace Science 40, 65-81.

Jerden Jr., J.L, Sinha, A.K., 2003. Phosphate based immobilization of uranium in an oxidizing bedrock aquifer. Applied Geochemistry 18, 823-843.
作 phate mineralization in an oxidizing saprolite-soil profile: chemical weathering of the Coles Hill uranium deposit, Virginia. Chemical Geology 199, 129-157.

Kasioptas, A., Perdikouri, C, Putnis, C.V., Putnis, A, 2008. Pseudomorphic replacement of single calcium carbonate crystals by polycrystalline apatite. Mineralogical Magazine $72,77-80$.

Khosrawan-Sazedj, F., 1982. The crystal structure of meta-uranocircite II, Ba( $\left(\mathrm{UO}_{2}\right)_{2}\left(\mathrm{PO}_{4}\right)_{2} .6$ $\mathrm{H}_{2} \mathrm{O}$. Tschermaks Mineralogische und Petrograph ische 29, 193-204.

Locock, A.J., Burns, P.C., 2003. Crystal structures and synthesis of the copper-dominant members of the autunite and meta-autunite groups: torbernite, zeunerite, metatorbernite and metazeunerite. The Canadian Mineralogist 41, 489-502.

looock, A.J., Burns, P.C., Flynn, T.M., 2005. Structures of strontium- and barium-dominant compounds that contain the autunite-type sheet. The Canadian Mineralogist 43 721-733.

Miller, S.A., Taylor, J.C., 1986. The crystal structure of saleeite, $\mathrm{Mg}\left[\mathrm{UO}_{2} \mathrm{PO}_{4}\right]_{2} \cdot 10 \mathrm{H}_{2} \mathrm{O}$. Zeitschrift fur Kristallograhie 177, 247-253.

Murakami, T., Ohnuki, T., Isobe, H., Sato, T., 1997. Mobility of uranium during weathering. American Mineralogist 82, 888-899.

Murakami, T., Sato, T., Ohnuki, T., Isobe, H., 2005. Field evidence for uranium nanocrystallization and its implications for uranium transport. Chemical Geology 221, 117-126.

Naftz, D.L., Davis, J.A., Fuller, C.C. Morrison, S.J., Freethey, G.W., Feltcorn, E.M., Wilhelm, R.G., Piana, M.J., Joye, J., Rowland, R.C., 1999. Field demonstration of permeable reactive barriers to control radionuclide and trace-element contamination in groundwater from abandoned mine lands. In: Morganwalp, D.W., Buxton, H.T (Eds.), United States Geological Survey, Water-Resources Investigations, WRI-994018-A, pp. 282-288.

National Research Council, 1995. Technical Bases for Yucca Mountain Standards. The National Academies Press, Washington DC. 205 pp.

Ohnuki, T., lsobe, H., Yanase, N., Nagano, T., Sakamoto, T., Sekine, K., 1997. Change in sorption characteristics of uranium during crystallization of amorphous iron minerals. Journal of Nuclear Science and Technology 34, 1153-1158.

Payne, T.E., Edis, R, Herczeg, A.L, Sekine, K., Seo, Y., Waite, T.D., Yanase, 1992. Groundwater Chemistry. : All igator Rivers Analogue Final Report, vol. 7. AustralianNuclear Scienœe and Technology Organisation, Sydney. $185 \mathrm{pp}$.

Payne, T.E, Davis, J A., Waite, T.D., 1996. Uranium adsorption on ferrihydrite - effects of phosphate and humic acid. Radiochimica Acta 74, 239-243.

Payne, T.E., Edis, R., Fenton, B.R., Waite, T.D., 2001. Comparison of laboratory uranium sorption data with "in situ distribution coefficients" at the Koongarra uranium deposit, Northern Australia. Journal of Environmental Radioactivity 57, 35-55.

Petit, J.-C., Della Mea, G., Dran, J.-C, Magontheir, M.-C., Mando, P.A., Paccagnella, A., 1990. Hydrated layer formation during dissolution of complex silicate glasses and minerals. Geochimica et Cosmochimica Acta 54, 1941-1955.

Piret, P., Piret-Meunier, J., 1991. Composition chimique et structure cristalline de la phosphuranylite $\mathrm{Ca}\left(\mathrm{UO}_{2}\right)\left[\left(\mathrm{UO}_{2}\right)_{3}(\mathrm{OH})_{2}\left(\mathrm{PO}_{4}\right)_{2}\right]_{2} \cdot 12 \mathrm{H}_{2} \mathrm{O}$. European Journal of Mineralogy $3,69-77$.

Prazeres, C. M., 2011. Caracterização geoquimica, radiométrica e mineralógica de algumas mineralizações de urânio da região de Nisa. MSc Thesis, Universidade de Lisboa, $147 \mathrm{pp}$

Putnis, A., 2009. Mineral replacement reactions. In: Oelkers, E.H., Schott, J. (Eds.), Thermodynamics and Kinetics of Water-Rock Interaction, : Reviews in Mineralogy and Geochemistry, 70. The Mineralogical Society of America, Wasington DC, pp. 87-124

Ross, V., 1955. Studies on uranium (XXI): synthetic hydrogen-autunite. American Mineralogist 40,917-919.

Ross, M., Evans, H.T., Appleman, D.E., 1964. Studies of the torbernite minerals (11): the crystal structure of meta-torbernite. American Mineralogist 49, 1603-1621.

Sato. T., Murakami, T., Yanase, N., Isobe, H., Payne, T.E., Airey, P.I., 1997. Iron nodules scavenging uranium from groundwater. Environmental Science and Technolog 31, 2854-2858.

Snelling, AA. 1980. Uraninite and its alteration pıoducts, Koongarra uranium deposit. Uranium in the Pine Creek Geosyncline, International Atomic Energy Agency, Vienna, pp. 487-498.

Snelling, A.A., 1992. Geologic Setting. : Alligator Rivers Analogue Project Final Report, vol. 2. Australian Nuclear Science and Technology Organisation, Sydney. 118 pp.

Solá, A. R., 2007. Relações Petrogeoquimicas dos Maciços Graníticos do NE Alentejano, PhD Thesis, Universidade de Coimbra, $367 \mathrm{pp}$.

Stille, P., Gauthier-Lafaye, F., Jensen, K.A., Salah, S., Bracke, G., Ewing, R.C, Iouvat, D. Million, D., 2003. REE mobility in groundwater proximate to the natural fission reactor at Bagombé (Gabon). Chemical Geology 198, 289-304.

Stubbs, J.E., Elbert, D.C., Veblen, D.R., Veblen, L.A., 2007. Cation depletion during elec tron microprobe analysis of uranium phosphates. American Geophysical Union Fall Meeting. abstract \#V51A - 0324.

Vochten, R, 1990. Transformation of chernikovite and sodium autunite into lehnerite. American Mineralogist 75, 221-225.

Vochten, R.F., Piret, P., Goeminne, A., 1981. Synthesis, crystallographic data, solubility and electrokinetic properties of copper-uranylphosphate, nickel-uranylphosphate and cobalt-uranylphosphate. Bulletin de Mineralogie 104, 457-467.

Vochten, R., De Grave, E., Pelsmaekers, J., 1984. Mineralogical study of basschite in relation to its oxidation. American Mineralogist $69,967-978$.

Vochten, R.F., Van Haverbeke, L., Van Springel, K., 1992. Transformation of chernikovite into meta-uranocircite II, $\mathrm{Ba}\left(\mathrm{UO}_{2}\right)_{2}\left(\mathrm{PO}_{4}\right)_{2} \cdot 6 \mathrm{H}_{2} \mathrm{O}$ and study of its solubility. Mineralogical Magazine 56,367-372.

Wojciechowski, K., Wróblewsky, W., Brzózka, Z, 2003. Anion buffering in the intemal electrolyte resulting in extended durability of phosphate-selective electrodes. Analytical Chemistry 75, 3270-3273. 